Key Biodiversity Area Special Series

\title{
Key Biodiversity Areas in the Philippines: Priorities for Conservation
}

\author{
R.G.R. Ambal ${ }^{1}$, M.V. Duya ${ }^{2}$, M.A. Cruz $^{3}$, O.G. Coroza ${ }^{4}$, S.G. Vergara ${ }^{5}$, N. de Silva ${ }^{6}$, N. Molinyawe $^{7} \&$ \\ B. Tabaranza ${ }^{8,9}$
}

${ }^{1} 3 \mathrm{G}$ Sunvar Condominiums, 2135 A. Luna St. Pasay City 1300, Philippines

${ }^{2}$ Institute of Biology, University of the Philippines, Diliman, Quezon City 1101, Philippines

${ }^{3} 67(9 \mathrm{~A})$ Dao St., Marikina Heights, Marikina City 1810, Philippines

${ }^{4}$ Conservation International Philippines, 6 Maalalahanin St., Teachers Village, Diliman, Quezon City 1101, Philippines

${ }^{5}$ ASEAN Centre for Biodiversity, 3rd Floor ERDB Building, University of the Philippines, Forestry Campus, Los Banos, Laguna 4031, Philippines

${ }^{6}$ Conservation International, 2011 Crystal Drive, Suite 500, Arlington, VA 22202, USA

${ }^{7}$ Protected Areas and Wildlife Bureau-Department of Environment and Natural Resources, Diliman, Quezon City 1101, Philippines

${ }^{8}$ Haribon Foundation, 2/F Santos and Sons Building 973 Aurora Boulevard, Quezon City 1109 Philippines

${ }^{9}$ Current address: 1/9 Patricia Avenue, Hilcrest, South Australia 5086, Australia

Email: ${ }^{1}$ rgrambal@gmail.com (corresponding author), ${ }^{2}$ lizavduya@gmail.com, ${ }^{3}$ mrabella@gmail.com, ${ }^{4}$ ocoroza@conservation.org,

${ }^{5}$ sheila_vergara@yahoo.com, ${ }^{6}$ ndesilva@conservation.org, ${ }^{7}$ normsmolinyawe@yahoo.com, ${ }^{8}$ tabaranzablas@yahoo.com

Date of publication (online): 06 August 2012 Date of publication (print): 06 August 2012 ISSN 0974-7907 (online) | 0974-7893 (print)

\section{Manuscript details:}

Ms \# 02995

Received 08 November 2011

Final revised received 15 January 2012

Finally accepted 24 May 2012

Citation: Ambal, R.G.R., M.V. Duya, M.A Cruz, O.G. Coroza, S.G. Vergara, N. de Silva, N. Molinyawe \& B. Tabaranza (2012). Key Biodiversity Areas in the Philippines: Priorities for Conservation. Journal of Threatened Taxa 4(8): 2788-2796.

Copyright: (c) R.G.R. Ambal, M.V. Duya, M.A. Cruz, O.G. Coroza, S.G. Vergara, N. de Silva, N. Molinyawe \& B. Tabaranza 2012. Creative Commons Attribution 3.0 Unported License. JoTT allows unrestricted use of this article in any medium for non-profit purposes, reproduction and distribution by providing adequate credit to the authors and the source of publication.

For Author Details, Author Contribution and Acknowledgements see end of this article.
Abstract: A process for identifying Key Biodiversity Areas (KBAs) for the Philippines was undertaken in two phases. The 128 terrestrial and freshwater KBAs were identified in 2006 and the 123 marine KBAs were identified in 2009. A total of 228 KBAs resulted from the integration of the terrestrial, freshwater and marine KBAs. These KBAs represent the known habitat of 855 globally important species of plants, corals, molluscs, elasmobranchs, fishes, amphibians, reptiles, birds and mammals in the country. Inclusion of these KBAs in the country's protected area system will be a significant step towards ensuring the conservation of the full scope of the country's natural heritage.

Keywords: Conservation priorities, irreplaceability, key biodiversity areas, Philippines, vulnerability.

\section{INTRODUCTION}

The Philippines is the world's second largest archipelago with more than 7,100 distinct islands covering an estimated 30 million hectares. It lies in the western Pacific Ocean and is geographically part of Southeast Asia, a region that occupies a mere three percent of the earth's total surface, yet is home to 20 percent of all known species of plants and animals.

The complex geological history of the Philippines has resulted in an extraordinary wealth of biodiversity, one of the highest concentrations of terrestrial vertebrate life on earth (Brown \& Diesmos 2009). The country’s marine ecosystems are equally diverse and unique. The archipelago is

The Key Biodiversity Area series documents the application of the concept and showcases the results from various parts of the world. The series is edited under the auspices of the IUCN World Commission on Protected Areas/Species Survival Commission Joint Task Force on 'Biodiversity and Protected Areas', with the editors supported by BirdLife International, Conservation International, IUCN, National Fish \& Wildlife Foundation, NatureServe, Parks Canada, and Plantlife International.

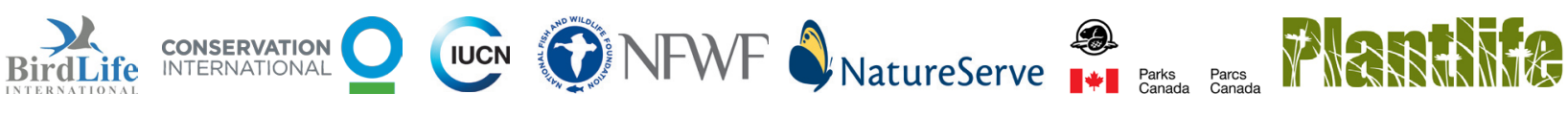


surrounded by shallow, warm seas that support the richest coral reef community on the planet, labeled the "center of marine diversity" by Carpenter \& Springer (2005). With more than 20,000 endemic species, the Philippines is recognized as a megadiverse country, one of 17 nations that, together, hold two-thirds of earth's biological diversity (Mittermeier et al. 1999).

However, continued exploitation and destruction of natural resources has led to the depletion of the country's unique and valuable biodiversity. Despite the greater understanding of Philippine biodiversity gained in the last decade, the onslaught of biodiversity loss has continued, albeit compensated by some conservation successes (Posa et al. 2008). Without timely intervention, further degradation of resources will continue and may eventually result in species extinction.

Defining conservation priorities is essential to minimizing biodiversity loss (Brooks et al. 2006) as it ensures that conservation action focuses on the species at the greatest risk of extinction and on the sites that are most important for their protection. The key biodiversity area (KBAs) approach was initiated in the Philippines to help the government and stakeholders prioritize conservation action and devise geographically specific strategies that protect the individual species and safeguard representative habitats (Edgar et al. 2008).

This paper integrates and summarizes the results of the KBA identification process undertaken for the country.

\section{METHODS}

The KBA definition process in the Philippines was initiated by Conservation International Philippines (CIP), Haribon Foundation and the Protected Areas and Wildlife Bureau (PAWB) of the Department of Environment and Natural Resources (DENR), with support from the Critical Ecosystem Partnership Fund (CEPF), a global program that provide grants for nongovernmental and private sector organizations to help protect Earth's most biologically rich yet threatened areas. KBAs have become the standard conservation target definition for CEPF Investments, not only in the Philippines but in other countries as well.

KBA identification in the Philippines involved two separate initiatives to identify terrestrial, freshwater and marine KBAs. The terrestrial and freshwater KBA identification process was completed in 2006 with KBAs identified based on the presence of globally threatened and/or restricted-range species of freshwater fish, amphibians, reptiles, birds, mammals and congregatory species of birds. This built on the process led by the Haribon Foundation to identify Important Bird Areas (IBA) (Mallari et al. 2001) and was also informed by specialist-driven identification of conservation priority areas (CPA) through the Philippine Biodiversity Conservation Priority Process (Ong et al. 2002). Terrestrial plants were not included in the analysis, because comprehensive data on their distributions and conservation status has not yet been compiled. In 2008, the marine KBA identification process was initiated and was completed in 2009. Marine KBAs were identified for seaweeds and seagrasses, corals, molluscs, elasmobranchs, reef fishes, marine turtles, sea- and small island-specialist birds, and marine mammals. The results of the two KBA definition processes were then combined and further refined to derive an integrated set of KBAs.

Identification of KBAs for both terrestrial and marine areas followed the process outlined in Langhammer et al. (2007). The criteria of vulnerability and irreplaceability were both applied. Vulnerability was triggered by the confirmed presence of one or more globally threatened species, classified as Critically Endangered (CR), Endangered (EN), and Vulnerable (VU) based on the IUCN Red List of Threatened Species (http://www.iucnredlist.org). The suggested threshold of 10 pairs or 30 individuals for species classified as VU (Langhammer et al. 2007) was not applied due to the lack of population data for majority of the trigger species. The 2004 IUCN Red List was used in the terrestrial KBA definition process, while the 2008 IUCN Red List was used in the marine KBA definition process. Irreplaceability was triggered by the confirmed presence of geographically concentrated species. Only two of the four sub-criteria of irreplaceability were used in both processes: the presence of species with restricted ranges and globally significant congregations. The restricted-range subcriterion was used to identify sites for species of known conservation concern from taxonomic groups which had not at the time been assessed for the IUCN Red List of Threatened Species. The congregations 
sub-criterion was only utilized for birds, based on Important Bird Area data (Mallari et al. 2001).

An initial analysis of trigger species, species that satisfies the criteria of vulnerability and/or irreplaceability, was done through a review of the pertinent literature and initial talks with experts on both processes. Species occurrence and distribution data for the trigger species were obtained from survey/ assessment reports, scientific reports, published literature, museum records and expert accounts. Point locality data for each trigger species were then plotted on a map and overlaid with data for other trigger species belonging to the same taxonomic group. KBA boundaries were delineated primarily based on whatever information was available on the habitat requirements and affinities of the trigger species. Initial KBA maps for each taxonomic group were then produced and were reviewed and validated through a series of meetings with experts. The final terrestrial, freshwater and marine KBA maps are the result of the overlays of the KBA maps of the different taxonomic groups.

For the terrestrial KBA boundaries, in most cases the IBA and CPA boundaries were followed (Conservation International et al. 2006). However, refinements and adjustments were made in areas where the IBA or CPA boundaries did not cover the habitat of other trigger species or to exclude areas that had been cleared or converted for human use since they were originally identified (e.g. farms, settlements, and major transportation corridors) or for management considerations (e.g. municipal boundaries or adjacent protected areas). For trigger species found within existing protected areas, the KBA followed the protected area boundary.

Marine KBA boundaries mostly followed natural features such as reef edges or depth contours, to include the largest extent possible of remaining habitat of the trigger species (Conservation International et al. 2009). In some cases, the boundaries correspond to existing management units, e.g. marine protected areas, designated sanctuaries, or follow municipal boundaries. The boundaries were also refined to exclude, as much as possible, areas that have been converted to human use, such as fish farms, port areas and major transportation corridors. Land areas were excluded from marine KBA boundaries. Exceptions include the nesting sites of sea turtles, wherein the beach and some inland mangrove areas were included.

Integration of the terrestrial KBAs and marine KBAs involved the overlay of the two map layers in ArcView. Overlapping terrestrial and marine KBAs were identified and a larger boundary, encompassing all the overlapping individual KBAs, was established to merge them into a single KBA. In some cases, two or more adjacent KBAs were also merged as a single $\mathrm{KBA}$ to support the habitat requirements of some of the trigger species. Socio-political parameters were also considered in the boundary delineation where information was available or applicable. Google Earth was used as an additional tool for refining the boundaries of the KBAs. Using the high resolution Quickbird imagery available for some areas in Google Earth, areas that have been cleared or converted to other land use were excluded, including ports and high density human settlements along the coast while, in some cases, existing KBA boundaries were expanded to include adjacent areas of suitable habitat.

\section{RESULTS}

A total of 228 key biodiversity areas were identified based on the integrated results of the 128 terrestrial KBAs identified in 2006 and the 123 marine KBAs identified in 2009. The terrestrial KBAs cover $20 \%$ of the country's land area, which includes the majority

Table 1. Summary details of the KBAs included within the analysis.

\begin{tabular}{|l|c|c|c|c|c|c|}
\hline $\begin{array}{l}\text { KBAs by ecosystem } \\
\text { coverage }\end{array}$ & Area $\left.\mathbf{( k m}^{2}\right)$ & \# of KBAs & \% of KBAs & $\begin{array}{c}\text { \# of KBAs } \\
\text { Protected }\end{array}$ & $\begin{array}{c}\text { \# of KBAs } \\
\text { Partially Protected }\end{array}$ & $\begin{array}{c}\text { \# of KBAs } \\
\text { Unprotected }\end{array}$ \\
\hline Terrestrial only & 51,249 & 101 & $44 \%$ & 27 & 25 & 49 \\
\hline Marine only & 19,601 & 77 & $34 \%$ & 8 & 6 & 63 \\
\hline Terrestrial and Marine & 35,702 & 50 & $22 \%$ & 15 & 10 & 25 \\
\hline Total & 106,552 & 228 & $100 \%$ & 50 & 41 & 137 \\
\hline
\end{tabular}


of the remaining terrestrial natural habitats, while the marine KBAs covered only $1.93 \%$ of the country's marine area or Exclusive Economic Zone (EEZ). Some $44 \%$ of the sites identified are terrestrial KBAs, $34 \%$ are marine and $22 \%$ include both marine and terrestrial areas (Table 1). Fifty (22\%) of the KBAs are existing protected areas, $41(18 \%)$ are partially protected, and the remaining $60 \%$ are unprotected (Table 1, Image 1).
The Philippine KBAs represent the known habitat of 855 species, 396 globally threatened and 398 restricted-range species of plants, corals, molluscs, elasmobranchs, fishes, amphibians, reptiles, birds and mammals and 61 species of congregatory birds (Table 2). The majority of the globally threatened species would also have triggered the irreplaceability criteria had these been comprehensively applied, but for threatened species, we only identified sites under

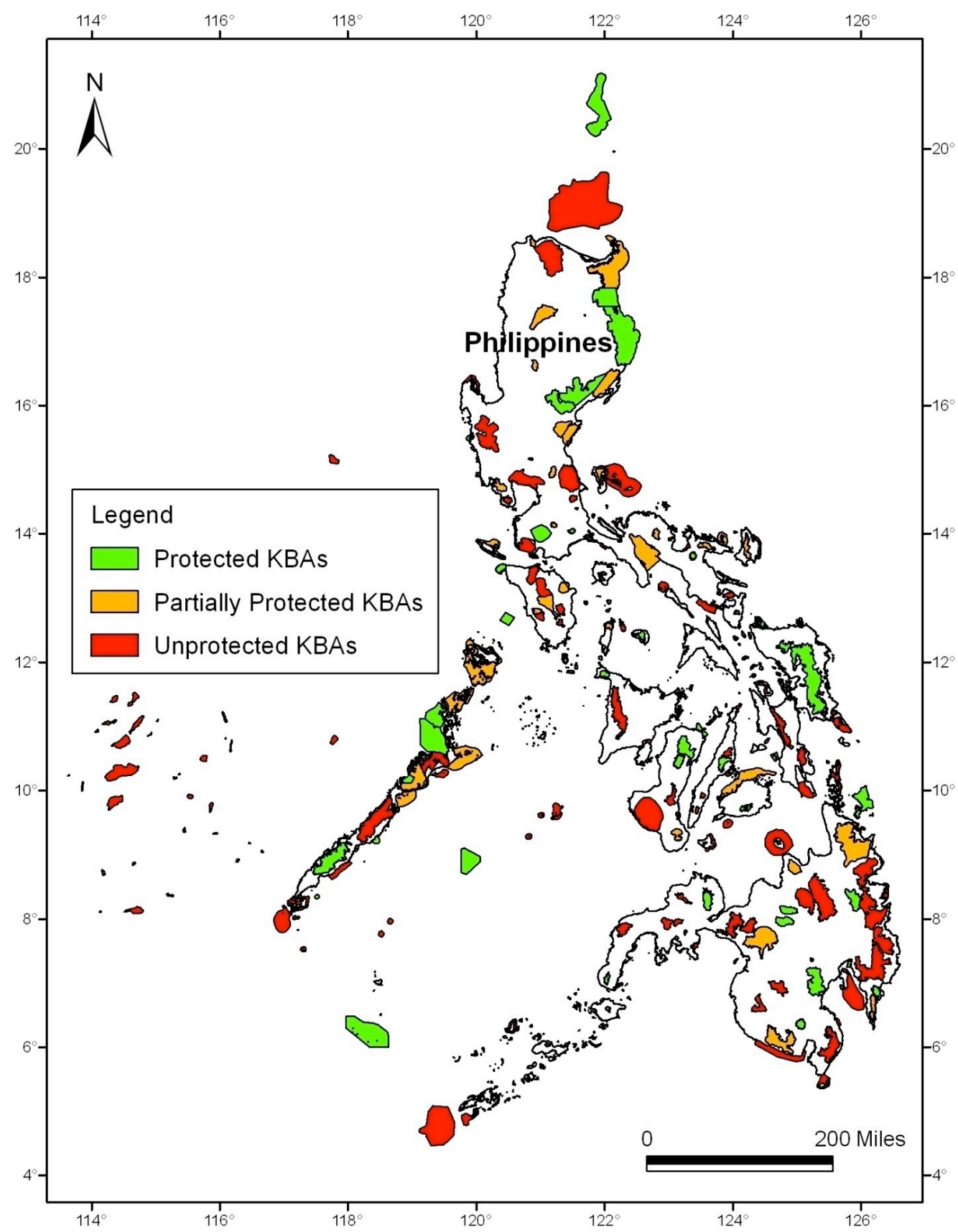

Image 1. Map of Philippines showing delineated KBA boundaries showing protected, partially protected and unprotected KBAs. 
the vulnerability criterion, not the irreplaceability criterion. Corals have the highest number of species which trigger site identification under the vulnerability criterion, with 176 species triggering a total of 49 KBAs. The irreplaceability trigger species list is dominated by birds (partly because the congregations sub-criterion was applied for birds but not other taxonomic groups), with 228 species triggering a total of 93 KBAs (Table $2 \& 3$ ).

A total of 243 species are found at only a single KBA while $40 \mathrm{KBAs}$ were identified based on the presence of a single trigger species (Table 4). Two species of globally threatened birds triggered the greatest number of KBAs; Spizaetus philippensis (VU) occurs at $48 \mathrm{KBAs}$ while Cacatua haematuropygia (CR) triggers 44 KBAs. The KBAs with the greatest number of trigger species are Balayan Bay, with 172 species, followed by Tingloy with 167 . Both sites are marine KBAs. Large numbers of globally threatened corals, 169 and 166 species respectively, have been documented occurring within these two sites. A third of the total number of KBAs were triggered by 20 or more species. Only two percent of the trigger species are found in 20 or more KBAs (Table 4).

Table 2. Number of species triggering each of the KBA criteria/sub-criteria for each taxonomic group. Many species which trigger KBA identification under the vulnerability criterion would also trigger the irreplaceability criteria.

\begin{tabular}{|l|c|c|c|c|c|c|}
\hline \multirow{2}{*}{ Taxonomic Group } & \multicolumn{3}{|c|}{ Vulnerability } & \multicolumn{2}{c|}{ Irreplaceability } & \multirow{2}{*}{ Total } \\
\cline { 2 - 7 } & CR & EN & VU & $\begin{array}{c}\text { Restricted- } \\
\text { range }\end{array}$ & $\begin{array}{c}\text { Congregations/ } \\
\text { aggregations }\end{array}$ & \\
\hline Seaweeds/Seagrass & 0 & 0 & 0 & 17 & 0 & 17 \\
\hline Corals & 0 & 9 & 167 & 1 & 0 & 177 \\
\hline Mollusks & 0 & 0 & 2 & 0 & 0 & 2 \\
\hline Elasmobranchs & 0 & 1 & 8 & 0 & 0 & 9 \\
\hline Reef Fishes & 0 & 1 & 5 & 2 & 0 & 8 \\
\hline Freshwater Fishes & 14 & 1 & 6 & 9 & 0 & 30 \\
\hline Amphibians & 1 & 7 & 40 & 25 & 0 & 73 \\
\hline Reptiles & 4 & 4 & 2 & 129 & 0 & 139 \\
\hline Birds & 13 & 14 & 44 & 167 & 61 & 299 \\
\hline Mammals & 7 & 15 & 31 & 48 & 0 & 101 \\
\hline Total & 39 & 52 & 305 & 398 & 61 & 855 \\
\hline
\end{tabular}

Table 3. Numbers of KBAs triggered by each criteria/sub-criteria for each taxonomic group.

\begin{tabular}{|l|c|c|c|c|c|}
\hline \multirow{2}{*}{ Taxonomic Group } & \multicolumn{3}{|c|}{ Vulnerability } & \multicolumn{2}{c|}{ Irreplaceability } \\
\cline { 2 - 6 } & CR & EN & VU & Restricted-range & $\begin{array}{c}\text { Congregations/ } \\
\text { Aggregations }\end{array}$ \\
\hline Seaweeds/Seagrass & 0 & 0 & 0 & 16 & 0 \\
\hline Corals & 0 & 7 & 45 & 1 & 0 \\
\hline Mollusks & 0 & 0 & 15 & 0 & 0 \\
\hline Elasmobranchs & 0 & 1 & 14 & 0 & 0 \\
\hline Reef Fishes & 0 & 20 & 30 & 3 & 0 \\
\hline Freshwater Fishes & 1 & 1 & 3 & 3 & 0 \\
\hline Amphibians & 1 & 30 & 71 & 37 & 0 \\
\hline Reptiles & 40 & 26 & 16 & 67 & 0 \\
\hline Birds & 85 & 54 & 121 & 78 & 17 \\
\hline Mammals & 14 & 43 & 81 & 39 & 0 \\
\hline Total & 141 & 182 & 396 & 244 & 17 \\
\hline
\end{tabular}


Table 4. Frequency distribution of the number of KBAs per trigger species and the number of trigger species per KBA.

\begin{tabular}{|c|c|c|}
\hline$n$ & $\begin{array}{c}\text { \# KBAs holding } n \text { trigger } \\
\text { species }\end{array}$ & $\begin{array}{l}\text { \# trigger species } \\
\text { occurring in } n \text { KBAs }\end{array}$ \\
\hline 1 & 40 & 243 \\
\hline 2 & 32 & 188 \\
\hline 3 & 15 & 111 \\
\hline 4 & 9 & 62 \\
\hline 5 & 9 & 50 \\
\hline 6 & 5 & 37 \\
\hline 7 & 4 & 27 \\
\hline 8 & 8 & 30 \\
\hline 9 & 3 & 19 \\
\hline 10 & 1 & 14 \\
\hline 11 & 6 & 8 \\
\hline 12 & 2 & 11 \\
\hline 13 & 4 & 7 \\
\hline 14 & 3 & 10 \\
\hline 15 & 3 & 7 \\
\hline 16 & 6 & 3 \\
\hline 17 & 3 & 5 \\
\hline 18 & 2 & 7 \\
\hline 19 & 4 & 1 \\
\hline 20 & 4 & 3 \\
\hline 21 & 2 & 1 \\
\hline 22 & 1 & 2 \\
\hline 23 & 5 & 2 \\
\hline 24 & 3 & 0 \\
\hline 25 & 3 & 0 \\
\hline 26 & 2 & 0 \\
\hline 27 & 3 & 1 \\
\hline 28 & 0 & 0 \\
\hline 29 & 3 & 0 \\
\hline 30 & 2 & 0 \\
\hline
\end{tabular}

\begin{tabular}{|c|c|c|}
\hline $\boldsymbol{n}$ & $\begin{array}{c}\text { \# KBAs holding } \boldsymbol{n} \text { trigger } \\
\text { species }\end{array}$ & $\begin{array}{c}\text { \# trigger species } \\
\text { occurring in } \boldsymbol{n} \text { KBAs }\end{array}$ \\
\hline 31 & 3 & 1 \\
\hline 32 & 2 & 0 \\
\hline 33 & 2 & 1 \\
\hline 34 & 2 & 0 \\
\hline 35 & 1 & 0 \\
\hline 36 & 0 & 1 \\
\hline 37 & 5 & 1 \\
\hline 38 & 1 & 0 \\
\hline 39 & 3 & 0 \\
\hline 40 & 2 & 0 \\
\hline 41 & 0 & 0 \\
\hline 42 & 0 & 0 \\
\hline 43 & 2 & 0 \\
\hline 44 & 1 & 1 \\
\hline 45 & 1 & 0 \\
\hline 46 & 1 & 0 \\
\hline 47 & 1 & 0 \\
\hline 48 & 0 & 0 \\
\hline 49 & 1 & 0 \\
\hline 50 & 1 & 0 \\
\hline 51 & 1 & 0 \\
\hline 55 & 1 & 0 \\
\hline 56 & 1 & 0 \\
\hline 57 & 1 & 0 \\
\hline 63 & 1 & 0 \\
\hline 67 & 1 & 0 \\
\hline 88 & 1 & 0 \\
\hline 97 & 1 & 0 \\
\hline 167 & 1 & 0 \\
\hline 172 & 1 & 0 \\
\hline
\end{tabular}

\section{DISCUSSION}

The identification of Philippine KBAs builds on the previous conservation priority-setting initiatives in the country. Conservation Priority Areas (CPA) were identified and delineated in 2000 based on the combined inputs and consensus of experts making best use of available data. The resulting priority areas encompassed large areas that did not consider management potential, and lacked quantitative data to show presence of target species needing conservation action. In 2001, Haribon Foundation and BirdLife International identified 117 Important Bird Areas

(IBAs). The IBAs were identified by spatially referencing all relevant existing information on globally threatened, restricted range, and congregatory bird species. The KBA process built from these two priority-setting initiatives by refining the previous results by using the most recent, spatially referenced, and validated information on a wide range of taxa requiring conservation intervention.

KBA identification has facilitated the identification of gaps in the national protected area system, with more than half of the KBAs unprotected. The KBAs which do not overlap with protected areas can be considered as "representation gaps" whereas KBAs which only 
Table 5. Summary of data for threatened species occurring at only one KBA globally. (Sites already recognized as AZE sites are marked *)

\begin{tabular}{|c|c|c|}
\hline KBA & Species & $\begin{array}{l}\text { IUCN Red List } \\
\text { category }\end{array}$ \\
\hline Mt. Halcon & $\begin{array}{l}\text { Anonymomys mindorensis } \\
\text { Apomys gracilirostris }\end{array}$ & $\begin{array}{l}\text { VU } \\
\text { VU }\end{array}$ \\
\hline $\begin{array}{l}\text { Mts. Banahaw-San Cristobal Protected } \\
\text { Landscape }\end{array}$ & $\begin{array}{l}\text { Platymantis indeprensus } \\
\text { Platymantis montana } \\
\text { Platymantis naominae } \\
\text { Platymantis banahao }\end{array}$ & $\begin{array}{l}\text { VU } \\
\text { VU } \\
\text { VU } \\
\text { VU }\end{array}$ \\
\hline Lake Manguao & Puntius manguaoensis & VU \\
\hline Mt. Mantalingahan & $\begin{array}{l}\text { Palawanomys furvus } \\
\text { Sundascuirus rabori }\end{array}$ & $\begin{array}{l}\text { EN } \\
\text { VU }\end{array}$ \\
\hline South and North Gigante Island* & Platymantis insulatus & CR \\
\hline Mt. Canlaon Natural Park* & Ptilinopus arcanus & CR \\
\hline Southwestern Negros & Platymantis spelaeus & EN \\
\hline Central Panay Mountains & Crateromys heanyi & EN \\
\hline Cuernos de Negros $^{*}$ & $\begin{array}{l}\text { Stachyris nigrorum } \\
\text { Crocidura negrina }\end{array}$ & $\begin{array}{l}\text { EN } \\
\text { EN }\end{array}$ \\
\hline Mt. Kambinliw and Mt. Redondo* & Crateromys australis & CR \\
\hline Mt. Kitanglad Range & Alionycteris paucidentata & VU \\
\hline Lake Lanao & $\begin{array}{l}\text { Cephalakompsus pachycheilus } \\
\text { Mandibularca resinus } \\
\text { Ospatulus truncatulus } \\
\text { Puntius amarus } \\
\text { Puntius baoulan } \\
\text { Puntius clemensi } \\
\text { Puntius disa } \\
\text { Puntius flavifuscus } \\
\text { Puntius herrei } \\
\text { Puntius katolo } \\
\text { Puntius lanaoensis } \\
\text { Puntius manalak } \\
\text { Puntius tras } \\
\text { Spratellicypris palata } \\
\text { Ospatulus palaemophagus } \\
\text { Puntius lindog } \\
\text { Puntius sirang } \\
\text { Puntius tumba }\end{array}$ & $\begin{array}{l}\text { CR } \\
\text { CR } \\
\text { CR } \\
\text { CR } \\
\text { CR } \\
\text { CR } \\
\text { CR } \\
\text { CR } \\
\text { CR } \\
\text { CR } \\
\text { CR } \\
\text { CR } \\
\text { CR } \\
\text { CR } \\
\text { EN } \\
\text { VU } \\
\text { VU } \\
\text { VU }\end{array}$ \\
\hline Tawi-tawi Island* & $\begin{array}{l}\text { Anthracoceros montani } \\
\text { Gallicolumba menagei } \\
\text { Phapitreron cinereiceps }\end{array}$ & $\begin{array}{l}\text { CR } \\
\text { CR } \\
\text { EN }\end{array}$ \\
\hline
\end{tabular}

Thirty five threatened species are known to occur at a single KBA globally (Table 5). These 35 species trigger 12 KBAs, five of which are already recognized as Alliance for Zero Extinction (AZE) sites (AZE 2010) as holding the entire global population of at least one species listed as Critically Endangered or Endangered on the IUCN Red List. A further three sites revealed in this analysis (Southwestern Negros, Central Panay Mountains, and Lake Lanao) also meet the AZE criteria. Mt. Mantalingahan was previously identified as an AZE site but was dropped in the 2010 AZE list after the Red List category of the Palawanomys furvus was reclassified from Endangered to Data Deficient in 2008.

have partial or incomplete overlap with protected areas can be considered as "ecological gaps". These analyses therefore, provide a guide for investments by government and civil society towards a truly representative protected area system that encompasses the full scope of the country's natural heritage.

The KBAs are currently being used by the Philippine government as means of identifying where biodiversity conservation projects are to be implemented. A milestone in the conservation effort in the country is the signing by the President of Executive Order 578 in 2006 declaring all KBAs to be "critical habitats" and directed the DENR to promulgate guidelines for their management and protection. The government has also taken the KBA initiative one step further by prioritizing efforts in developing an agreed set of criteria that can be used to assess and prioritize conservation action and investments in KBAs. Conservation investments have declined in recent years, and knowing that the safeguarding of some 
KBAs is more urgent than others, has necessitated the need to prioritize conservation action amongst KBAs identified till date. The actual prioritization of KBAs and planning the appropriate conservation action on the ground requires more detailed socio-political and economic data that this analysis has not been able to provide. Further studies should be initiated to gather information that would help assess the levels of threat within each KBA and the opportunities available to be able to focus investments in areas where conservation impacts would be greater.

The network of KBAs identified by this analysis does not mean that all priority sites in the country have been identified. Many globally important and restricted-range species have not been included in this analysis. Most plants have not yet been considered and it is known that the country is home to some of the most threatened habitats and species of plants in the world, with at least 694 taxa of vascular plants and mosses included in the threatened plants list of Fernando et al. (2008).

Furthermore, a number of additional candidate KBAs have been identified, although they are not included in this analysis. A total of 51 terrestrial and freshwater sites were identified as candidate KBAs. These are sites that have been identified as conservation priority areas by previous priority-setting initiatives that need further validation as to the presence of trigger species. The 126 marine candidate KBAs were identified for mangroves, seagrass and seaweeds, corals, echinoderms, molluscs, elasmobranchs, sea snakes, marine turtles, sea birds, and marine mammals. These sites are suspected to be important for conservation but at present do not have adequate data. These sites are currently targeted as priorities for research and it is hoped that soon new data will become available to validate and confirm the presence of trigger species in these areas.

KBA identification is an iterative process. As new data become available KBA boundaries are likely to be modified and new KBAs identified. Some species may also undergo changes in their conservation status that can also affect the priority status of the KBAs they trigger. For example, the subset of KBAs identified as AZE sites in the country has undergone major changes, with six sites removed from the 2010 AZE list. These include Mt. Mantalingahan, Mt. Malindang, Mt. Isarog, Northern Sierra Madre Natural Park, Siburan, and Ilin
Is. This change is mainly due to new information on distribution or conservation status of the trigger species that has resulted on the species no longer satisfying the AZE criteria (although all six remain as KBAs). Nevertheless, the KBA list represents the best current assessment of those sites where safeguard mechanisms are necessary in order to allow the Philippines' unique but threatened biodiversity to persist into the future.

\section{REFERENCES}

AZE (2010). Alliance for Zero Extinction: 2010 Update. Downloaded from http://www.zeroextinction.org. Accessed 15 November 2010.

Brooks T.M., R.A. Mittermeier, G.A.B. Fonseca, J. Gerlach, M. Hoffmann, J.F. Lamoreux, C.G. Mittermeier, J.D. Pilgrim \& A.S.L. Rodrigues (2006). Global biodiversity conservation priorities. Science 313: 58-61.

Brown, R.M. \& A.C. Diesmos (2009). Philippines, Biology, pp. 723-732. In: Gillespie, R. \& D. Clague (eds.). Encyclopedia of Islands. University of California Press, Berkeley.

Carpenter, K.E. \& V.G. Springer (2005). The center of the center of marine shore fish biodiversity: the Philippine Islands. Environmental Biology of Fishes 72: 467-480.

Conservation International Philippines, Department of Environment and Natural Resources-Protected Areas and Wildlife Bureau, and Haribon Foundation (2006). Priority sites for conservation in the Philippines: Key Biodiversity Areas. Quezon City, Philippines, 24pp.

Conservation International Philippines, Department of Environment and Natural Resources-Protected Areas and Wildlife Bureau, and Department of Agriculture Bureau of Agriculture and Aquatic Resources (2009). Marine Key Biodiversity Areas. CD and Map.

Edgar, G.J., P.F. Langhammer, G. Allen, T.M. Brooks, J. Brodie, W. Crosse, N. De Silva, L. Fishpool, M.N. Foster, D. Knox, J.E. McCosker, R. McManus, A. Miller \& R. Mugo (2008). Key Biodiversity Areas as Globally Significant Target Sites for The Conservation of Marine Biological Diversity. Aquatic Conservation: Marine and Freshwater Ecosystems, 18: 969-983.

Fernando, E.S., L.L. Co, D.A. Lagunzad, W.S. Gruezo, J.F. Barcelona, D.A. Madulid, A. Baja-Lapis, G.I. Texon, A.C. Manila \& P.M. Zamora (2008). Threatened plants of the Philippines: a preliminary assessment. Asia Life Sciences, Supplement 3: 1-52.

IUCN (2004). The 2004 IUCN Red List of Threatened Species. Downloaded from http://www.redlist.org. Accessed 13 March 2006.

IUCN (2008). The 2008 IUCN Red List of Threatened Species. Downloaded from http://www.redlist.org. Accessed December 2008.

Langhammer, P.F., M.I. Bakarr, L.A. Bennun, T.M. Brooks, 
R.P. Clay, W. Darwall, N. De Silva, G.J. Edgar, G. Eken, L.D.C. Fishpool, G.A.B. de Fonseca, M.N. Foster, D.H. Knox, P. Matiku, E.A. Radford, A.S.L. Rodrigues, P. Salaman, W. Sechrest \& A.W. Tordoff (2007). Identification and Gap Analysis of Key Biodiversity Areas: Targets for Comprehensive Protected Area Systems. IUCN Best Practice Protected Area Guidelines Series No. 15. IUCN, Gland, Switzerland.

Mallari, N.A.D., B.R. Tabaranza, Jr. \& M.J. Crosby (2001). Key Conservation Sites in the Philippines: a Haribon Foundation and Birdlife International Directory of Important Bird Areas. Department of Environment and Natural Resources and Bookmark Inc. Makati City: Bookmark, 485pp.

Mittermeier, R.A., N. Myers, P. Robles-Gil, \& C.G. Mittermeier (eds.) (1999). Hotspots. Earth's Biologically Richest and Most Endangered Terrestrial Ecoregions. CEMEX/Agrupación Sierra Madre, Mexico City, 432pp.

Ong, P.S., L.E. Afuang \& R.G. RosellAmbal (eds.) (2002). Philippine Biodiversity Conservation Priorities: A Second Iteration of the National Biodiversity Strategy and Action Plan. DepartmentofEnvironmentand Natural Resources-Protected Areas and Wildlife Bureau, Conservation International Philippines, Biodiversity Conservation ProgramUniversity of the Philippines Center for Integrative and Development Studies, and Foundation for the Philippine Environment, Quezon City, Philippines, 113pp.

Posa, M.R.C., A.C. Diesmos, N.S. Sodhi \& T.M. Brooks (2008). Hope for threatened tropical biodiversity: Lessons from the Philippines. BioScience 58: 231-240.

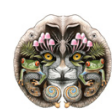

Author Details: Ruth Grace Ambal is a wildlife biologist that has been involved the past 10 years in identifying conservation priorities in the Philippines.

Melzar DuYa is a Senior Research Associate of the project entitled "Comprehensive Biodiversity Conservation and Monitoring Program of the Pantabangan-Carranglan Watershed, Pantabangan, Nueva Ecija, Luzon Island, Philippines" funded by the First Gen Hydro Power Corporation under the Institute of Biology, College of Science, UP Diliman, Quezon City, Philippines.

Margaux Cruz has a degree in MS Remote Sensing from the University of the PhilippinesDiliman. She has been working part-time as a remote sensing and GIS consultant for various projects for the past three years. She is currently affiliated with the Bureau of Fisheries and Aquatic Resources as a remote sensing consultant.

OLIVER CoRoza is with Conservation Internationa Philippines. He has 22 years of experience in applying cartographic modeling and GIS for natural resources management, remote sensing applications, biodiversity conservation land use and protected area planning, real estate management and facilities/utilities management.

SHella Vergara, a marine ecologist by training mobilized the marine KBA process with colleagues in the course of implementing the Sulu Sulawesi Seascape Initiative. She is now the Director for Biodiversity Information Management at the ASEAN Centre for Biodiversity.

Namal De Silva is Director of Conservation Priorities and Outreach in the Science + Knowledge Division of Conservation International. She is also a doctoral student in Curriculum and Instruction at the George Washington University Graduate School of Education and Human Development.

Norma Molinyawe is the Chief of the Biodiversity Management Division of the Protected Areas and Wildlife Bureau of the Department of Environment and Natural Resources, Philippines

BLAS TABARANZA was Haribon Foundation's resident scientist and Chief Operating Office before his retirement. He is a member of Birdlife International's Global Council 2008-2012 and president emeritus of the Wildlife Conservation Society of the Philippines.

Author Contribution: RGA spearheaded the process of identifying marine and terrestrial KBAs in the Philippines. MD, MC, and OC was part of the team that identified the Philippine KBAs. NDS provided advice and technical input.
SV provided support and input to the marine KBA identification. NM and BT provided support and input in the terrestrial KBA identification.

Acknowledgements: The identification of Philippine KBAs was made possible through the financial support of the Critical Ecosystem Partnership Fund for the terrestrial KBA process, and the generous support provided by the Walton Family Foundation through the Sulu-Sulawesi Seascape Project, implemented by Conservation International Philippines, for the marine KBA process. The KBA definition process would not have been completed without the support and input of all the experts/ individuals who have been generous in sharing information, participated in the numerous meetings/workshops and have unselfishly shared their data: J.M. Acebes, M.N. Alava, A.C. Alcala, E. Alcala, P.M. Aliño, R.A.N. Altamirano, A. Alvaran, P.A. Alviola, M.T.R. Aquino, D.S. Balete, F.B. Barangan, A.B. Barcelona, C.B. Batoy, P.D. Beldia, T. Blastique, D. Bravo, J.M.A. Bringas, R.M. Brown, G.L. Bueser, D. Cabahug, J.P.B. Cabansag, W. Campos, E. Capuli, A. Cariño, L. Casten, L.L. Co, C.C. Custodio, J.D. De Alban, A. De Guzman, G. dela Rosa Jr., M. Deocadez, A.C. Diesmos, M.L. Dolar, M.M Duya, E.G. Fortes, M. Fortes, H. Froyalde, J. Gatus, J.P. Gaudiano, J.C.T. Gonzalez, L.R. Heaney, V. Hilomen, J.C. Ibañez, N. Ingle, A.E. Jensen, S.M. Licuanan, W. Licuanan, N.A.D. Mallari, J.D. Matillano, T. Mildenstein, C. Nañola, S.P. Oliver, P.S. Ong, L.M. Paguntalan, M.J. Palomar, J. Pontillas, J. Primavera, H.R. Quiaoit, M.C. Quibilan, R.R. Quidlat, F.T. Quimpo, N. Ramoso, C. Reboton, E.L. Rico, E. Sabater, R. Sadaba, R.A. Salinas, B.R. Samaniego, M.R. Silvosa, D.G. Tabaranza, F. Torres Jr., G.C. Trono Jr., R.B. Trono, B. Vallejo, M. van Weerd, C.L. Villanoy, R.B. Villanueva, A. White, I. Widmann, P. Widmann, and A.A. Yaptinchay. Invaluable support was also provided by the following institutions: Conservation International Philippines (CIP), Protected Areas and Protected Areas and Wildlife Bureau of the Department of Environment and Natural Resources (PAWBDENR), Haribon Foundation, Foundation for the Philippine Environment (FPE), University of the Philippines - Center for Integrative Studies (UP-CIDS), Department of Agriculture - Bureau of Fisheries and Aquatic Resources (DA-BFAR), and University of the Philippines - Marine Science Institute (UP-MSI). The authors would like to thank two anonymous reviewers for their insightful review and valuable comments. We would also like to extend our gratitude to $\mathrm{Dr}$. Thomas Brooks for all his comments, inputs and support in the drafting and completion of this paper.

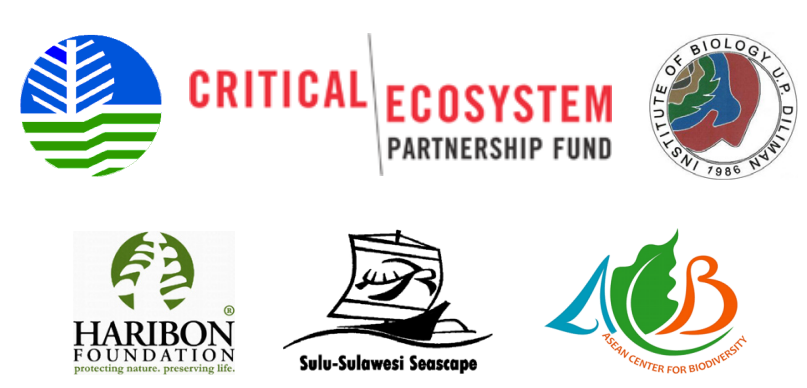

